\title{
Interplanting Some Soybean Cultivars with Mandarin Trees in Sandy Soil
}

\author{
M. A. F. Selim¹, Y. A. A. Hefny², Eman I. Abdel-Wahab³, Marwa Kh. A. Mohamed ${ }^{3}$ \\ ${ }^{1}$ Citrus Research Department, Horticulture Research Institute, Agricultural Research Center, Giza, Egypt \\ ${ }^{2}$ Crop Intensification Research Department, Field Crops Research Institute, Agricultural Research Center, Giza, Egypt \\ ${ }^{3}$ Food Legumes Research Department, Field Crops Research Institute, Agricultural Research Center, Giza, Egypt \\ Email:mofouad99@yahoo.com
}

How to cite this paper: Selim, M.A.F., Hefny, Y.A.A., Abdel-Wahab, E.I. and Mohamed, M.K.A. (2020) Interplanting Some Soybean Cultivars with Mandarin Trees in Sandy Soil. Agricultural Sciences, 11, 88-110. https://doi.org/10.4236/as.2020.111006

Received: December 10, 2019

Accepted: January 18, 2020

Published: January 21, 2020

Copyright $\odot 2020$ by author(s) and Scientific Research Publishing Inc. This work is licensed under the Creative Commons Attribution-NonCommercial International License (CC BY-NC 4.0). http://creativecommons.org/licenses/by-nc/4.0/

\begin{abstract}
Two-year field experiments were carried out at El-Kassasen Horticultural Research Station, Agricultural Research Center (ARC), Ismailia government, Egypt, during 2018 and 2019 summer seasons to evaluate some soybean cultivars for interplanting with mandarin trees to achieve high productivity of both crops, land usage and profitability under sandy soil conditions. The treatments were the combinations of two cropping systems (interplanting and solid cultures) and five soybean cultivars (Giza 21, Giza 22, Giza 35, Giza 82 and Giza 111). A strip plot design with three replications was used. Interplanting soybean cultivar Giza 22 with mandarin trees gave a higher total count of rhizobia in rhizosphere of mandarin roots after 75 days from soybean sowing than the other treatments in both seasons. The highest fruit weight and volume, total soluble solids (T.S.S.), fruit yields per tree and per ha were obtained by growing soybean cultivar Giza 22 or Giza 111 with mandarin compared with the other treatments in both seasons. With respect to soybean crop, interplanting soybean with mandarin trees decreased percentages of light intensity at the middle and bottom of the plant, chlorophylls a and $b$, as well as, plant dry weight after 75 days from soybean sowing compared with those of solid culture in both seasons. Soybean cultivars Giza 22 and Giza 82 had higher light intensity at the middle and bottom of the plant, as well as chlorophyll a, meanwhile soybean cultivars Giza 22 and Giza 111 had higher plant dry weight than the other soybean cultivars after 75 days from soybean sowing in both seasons. Soybean cultivar Giza 22 and Giza 111 had higher plant dry weight than the other soybean cultivars under interplanting and solid plantings in both seasons. Interplanting soybean with mandarin trees decreased soybean seed yield and its attributes compared with soybean solid culture in both seasons. Soybean cultivars Giza 111 and Giza 22
\end{abstract}


gave a higher number of pods per plant, seed yields per plant and per ha than the other cultivars in both seasons. Soybean cultivars Giza 111 and Giza 22 followed by Giza 82 recorded a higher number of pods per plant, seed yields per plant and per ha under interplanting and solid cultures than the other treatments in both seasons. Interplanting soybean cultivar Giza 22 and Giza 111 with mandarin trees achieved higher LER, LEC, total return and MAI than solid culture of mandarin. Growing four ridges of soybean cultivars Giza 22 or Giza 111 between mandarin trees cultivar Fremont had higher productivity, land usage and profitability than mandarin solid culture under sandy soil conditions.

\section{Keywords}

Interplanting, Mandarin, Soybean Cultivars, Total Count of Rhizobia, Competitive Relationships, Financial Return

\section{Introduction}

Citrus is a genus from Rutaceae family, subfamily Aurantoideael and there are several species in this genus; but there are major species such as sweet orange (Citrus sinensis (L.) Osbeck), mandarins group, grapefruits (Citrus paradisi), lime (Citrus aurantifolia) and sour orange (Citrus aurantium L.) as reported by Salem and Sheta [1]. Citrus is an important cash crops and an essential source of vitamin $\mathrm{C}$ for human diet. Citrus trees are of outstanding economical importance among fruit crops in Egypt. Mandarin (Citrus reticulata Blanco) is popular among citrus fruit trees grown in Egypt. Mandarin occupies the second planted citrus species after orange [2] and Egypt represents about 15\% of the total citrus production in the Mediterranean Basin and occupies the 3rd rank after Spain and Italy. Mandarin fruit is the cheap and rich source in vitamin C and A, as well as it contains small amounts of vitamin B6, carbohydrates and proteins. Usually, the fruits are eaten fresh; so internal fruit quality like fruit weight, peel colour, juice quantity and quality and easy peeling play an important role in fruit marketing. Adjusting nitrogen $(\mathrm{N})$ nutrition of citrus is considered an important and limited factor for improving production and fruit quality [3]. In this concern, Helail et al. [4] concluded that fertilizing Balady mandarin trees with different sources of $\mathrm{N}$ fertilizers enhanced tree fruiting traits expressed as fruit set, fruit drop, yield and fruit quality. Particularly, the major mandarin production in Egypt is confined to the local cultivar Balady that belongs to common Mediterranean mandarin group. Thus, the global production of mandarins in 2016 reached 32.8 million ton [5].

On the other hand, Lachungpa [6] revealed that interplanting some crops with mandarins provided farmers with increased food security and opportunities for cash flow. Thus, intercropping legumes in citrus orchards is beneficial for the citrus production. According to Srivastava et al. [7] and Aziz et al. [8], legumes 
improved fruit yield compared with sole orchard and such crops increased the yield of the main crop by fixing $\mathrm{N}$ biologically in the soil. The legume has been rated as the highest contribution of biological $\mathrm{N}$ fixation among the seed producers, with reports of rates of up to $450 \mathrm{~kg} \mathrm{~N} / \mathrm{ha}$ [9]. About $90 \%$ of the species within the family Leguminosae (Fabaceae) can fix atmospheric $\mathrm{N}$ through a symbiotic association with soil bacteria known as rhizobia [10]. Currently, the subject of biological $\mathrm{N}$ fixation is of great practical importance because the use of mineral $\mathrm{N}$ fertilizers has resulted in unacceptable levels of water pollution [11] [12]. It has been reported that various cultivars of legumes show significant differences in their ability to support BNF. Although $\mathrm{N}$ fixed by heterotrophic free-living bacteria is of minor importance as a mechanism for $\mathrm{N}$ input in arid soils [13], the potential of symbiotic $\mathrm{N}$ fixers is significantly higher than of those that are free living. Thus, the rate of potential $\mathrm{N}$ fixation is estimated by either nodule biomass [14], or aboveground biomass [15]. Consequently, a hallmark trait of legumes is their ability to develop root nodules and to fix $\mathrm{N}$ in symbiosis with compatible rhizobia [16]. However, biological $\mathrm{N}$ fixation itself is considered a sensitive indicator that precedes declining soybean [Glycine max (L.) Merrill] growth in response to environmental stressors [17]. Shading of citrus trees resilience in soybean has naturally been linked to bacterial driven $\mathrm{N}$ fixation. Most of $\mathrm{N}$ requirement for soybean is supplied through the $\mathrm{N}$-fixation process, which is a result of a beneficial relationship between the plant and specific soil bacteria. Early maturing soybean cultivars often have reduced $\mathrm{N}$-fixation ability and shorter $\mathrm{N}$-fixation periods than full-season cultivars [18]. Active fixation usually begins within 10 - 14 days later, around second and three trifoliate growth stages, at which point they can supply most of the plant's $\mathrm{N}$ requirements [19]. Accordingly, BNF in crop legumes not only reduces fertilizer costs but also improves soil fertility through crop rotation and intercropping. Therefore, the objective of this investigation was to evaluate some soybean cultivars for interplanting with mandarin trees to achieve high productivity of both crops, land usage and profitability under sandy soil conditions.

\section{Materials and Methods}

Two-year field experiments were carried out at El-Kassasen Horticulture Research, A.R.C., Ismailia Governorate (Lat. 30 35'30"N, Long. 32 $14^{\circ} 50^{\prime \prime} \mathrm{E}, 10 \mathrm{~m}$ a.s.l.), Egypt during 2018 and 2019 seasons to evaluate some soybean cultivars for interplanting with mandarin trees to achieve high productivity of both crops, land usage and profitability under sandy soil conditions. The treatments were the combinations of two cropping systems and five soybean cultivars as follows:

\subsection{Cropping Systems}

\subsubsection{Solid Cultures}

As a result of exist the alternate bearing in mandarin trees, four years old Fremont mandarin trees (on-year bearing) were growing in distance $3 \times 4 \mathrm{~m}$ apart 
(833 trees per ha) subjected to experiments in the first season, meanwhile other group of trees (in the same bearing status) were chosen in the second year. This system was used to estimate completive relationships (solid soybean, planting two soybean plants per hill, $25 \mathrm{~cm}$ apart, at both sides of eight ridges, $50 \mathrm{~cm}$ width (322,560 soybean plants/ha)). This system was used to estimate completive relationships.

\subsubsection{Interplanting Culture}

Plant densities of soybean crop was 50\% from solid crop condition (161,280 soybean plants/ha) (planting two soybean plants per hill, $25 \mathrm{~cm}$ apart, at both sides of four ridges, $50 \mathrm{~cm}$ width). The border ridges of soybean distanced at $0.75 \mathrm{~m}$ from mandarin trees.

\subsection{Soybean Cultivars}

Five soybean cultivars (Giza 21, Giza 22, Giza 35, Giza 82 and Giza 111) were used. A strip plot design with three replications was used. Cropping systems were randomly assigned to the vertical strips and soybean cultivars were allocated in the horizontal strips. Each strip plot was $48 \mathrm{~m}^{2}$ (8 $\mathrm{m}$ in length and $6 \mathrm{~m}$ in width). Soybean cultivars were sown on May 28th and 23rd at 2018 and 2019 summer seasons, respectively. Mechanical and chemical analyses of the soil (0 $60 \mathrm{~cm}$ ) were done by Water, Soil and Environment Research Institute, ARC (Table 1). Mechanical and chemical properties of the soil were determined using the methods described by Chapman and Pratt [20]. The average monthly temperature for the two years ranged from $16.8^{\circ} \mathrm{C}$ to $35.9^{\circ} \mathrm{C}$ in the first season and from $17.2^{\circ} \mathrm{C}$ to $36.4^{\circ} \mathrm{C}$ in the second season, the average relative humidity ranged from $50.0 \%$ to $61.0 \%$ in the first season and from $50.0 \%$ to $63.0 \%$ in the second season, meanwhile, the average sunshine hours ranged from 9.0 to 12.5 hours (Table 2). Table 3 shows pedigree, maturity group and growth habit of the tested soybean cultivars.

Drip irrigation system was used in all tested treatments by separated nets for each crop owing to control the amounts, time and methods of supply the fertilization (fertigation) request. Drip irrigation system was used in this study established on both sides of the tree trunk at a distance of one meter. Each tree provided with two droppers (discharge $4 \mathrm{~L} / \mathrm{h}$ ) and the time of operation was 4 hours/day ( $32 \mathrm{~L} /$ tree/day) throughout the period of study. At the beginning of each season, the experimental trees which subjected to solid or intreplanting culture received $0.5 \mathrm{~kg}$ calcium super phosphate $\left(15.5 \% \mathrm{P}_{2} \mathrm{O}_{5}\right)$ per tree mixed with $10 \mathrm{~kg} /$ tree organic manure added in rounded trenches close to the root system around the tree canopy. In addition, Nitrogen $(\mathrm{N})$ fertilizer was added at a rate of 178.5 and $357.0 \mathrm{~kg} \mathrm{~N}$ per ha as urea $(46.0 \% \mathrm{~N})$ divided by equal monthly doses from Feb. to Oct. under interplanting and solid cultures, respectively. Potassium (K) fertilizer was added at a rate of $238 \mathrm{~kg} \mathrm{~K}$ per ha as potassium sulfate (by three doses: March, June and Oct.) under both interplanting and solid cultures. Moreover, micronutrients (Fe 500 ppm, Mn 250 ppm \& Zn 250 ppm) were 
applied as foliar sprays 4 times/year, i.e. in Apr. June, Aug. and Oct. Under interplanting and solid cultures, calcium super phosphate $\left(15.5 \% \mathrm{P}_{2} \mathrm{O}_{5}\right)$ was applied at a rate of 238 and $476 \mathrm{~kg}$ per ha during soil preparation in the two summer seasons, $\mathrm{N}$ fertilizer was added at a rate of 71.4 and $142.8 \mathrm{~kg} \mathrm{~N}$ per ha as urea $(46.0 \% \mathrm{~N})$ and $\mathrm{K}$ fertilizer was added at a rate of 59.5 and $119 \mathrm{~kg} \mathrm{~K}$ per ha as potassium sulfate. Table 4 shows harvest dates of interplanting soybean with mandarin trees and solid cultures of both crops in both seasons.

Table 1. Mechanical and chemical properties of soil $(0-60 \mathrm{~cm})$ at experimental site before soybean planting.

\begin{tabular}{ccc}
\hline \multirow{2}{*}{ Depth of soil (0 - 60 cm) } & \multicolumn{2}{c}{ Growing season } \\
\cline { 2 - 3 } & First season (2018) & Second season (2019) \\
\hline Mechanical analysis & 12.43 & 12.19 \\
Clay (\%) & 2.02 & 1.93 \\
Silt (\%) & 85.55 & 85.88 \\
Sand (\%) & Sandy & Sandy \\
Texture & & 7.95 \\
Chemical analysis & 8.15 & 5.50 \\
pH & 5.00 & 9.50 \\
N (ppm) & 8.50 & 48.00 \\
P (ppm) & 42.00 & \\
K (ppm) &
\end{tabular}

Table 2. Meteorological information data of Ismailia Governorate (May - November) in 2018 and 2019 summer seasons.

\begin{tabular}{ccccccccc}
\hline Season & \multicolumn{3}{c}{ 2018 season } & \multicolumn{3}{c}{ 2019 season } \\
\hline Month & $\begin{array}{c}\text { Max. } \\
\text { temp } \\
\left({ }^{\circ} \mathrm{C}\right)\end{array}$ & $\begin{array}{c}\text { Min. } \\
\text { temp } \\
\left({ }^{\circ} \mathrm{C}\right)\end{array}$ & $\begin{array}{c}\text { Relative } \\
\text { humidity } \\
(\%)\end{array}$ & $\begin{array}{c}\text { Sunshine } \\
\text { Hrs. }\end{array}$ & $\begin{array}{c}\text { Max. } \\
\text { temp } \\
\left({ }^{\circ} \mathrm{C}\right)\end{array}$ & $\begin{array}{c}\text { Min. } \\
\text { temp } \\
\left({ }^{\circ} \mathrm{C}\right)\end{array}$ & $\begin{array}{c}\text { Relative } \\
\text { humidity } \\
(\%)\end{array}$ & $\begin{array}{c}\text { Sunshine } \\
\text { Hrs. }\end{array}$ \\
\hline May & 31.5 & 16.8 & 50 & 11.0 & 32.3 & 17.2 & 50 & 11.0 \\
June & 34.8 & 20.1 & 52 & 12.2 & 35.2 & 20.3 & 53 & 12.2 \\
July & 35.2 & 22.1 & 55 & 12.5 & 36.3 & 22.5 & 56 & 12.5 \\
August & 35.9 & 22.5 & 57 & 12.0 & 36.4 & 22.9 & 59 & 12.0 \\
September & 33.9 & 20.7 & 60 & 10.5 & 34.3 & 20.9 & 61 & 10.5 \\
October & 31.8 & 17.9 & 61 & 10.0 & 32.2 & 18.2 & 63 & 10.0 \\
November & 26.1 & 13.7 & 61 & 9.0 & 26.6 & 13.8 & 63 & 9.0 \\
\hline
\end{tabular}

Table 3. Pedigree, maturity group and growth habit of the tested soybean cultivars.

\begin{tabular}{cccc}
\hline Soybean cultivars & Pedigree & Maturity group & Growth habit \\
\hline Giza 21 & Crawford $\times$ Forrest & IV & Indeterminate \\
Giza 22 & Giza $21 \times 186$ K-73 & IV & Indeterminate \\
Giza 35 & Crawford $\times$ Celest $($ early) & III & Indeterminate \\
Giza 82 & Crawford $\times$ Maple presto & III & Indeterminate \\
Giza 111 & Crawford $\times$ Celest (late) & IV & Indeterminate \\
\hline
\end{tabular}


Table 4. Harvest dates of some soybean cultivars and mandarin trees under interplanting and solid cultures in both seasons.

\begin{tabular}{|c|c|c|c|c|}
\hline \multirow{3}{*}{ Treatments } & \multicolumn{4}{|c|}{ Growing season } \\
\hline & \multicolumn{2}{|c|}{ First season (2018) } & \multicolumn{2}{|c|}{ Second season (2019) } \\
\hline & Soybean & Mandarin & Soybean & Mandarin \\
\hline Interplanting culture & & & & \\
\hline Soybean cultivar Giza 21 + Mandarin & 3 August & 6 November & 27 July & 2 November \\
\hline Soybean cultivar Giza 22 + Mandarin & 1 September & 13 November & 24 August & 10 November \\
\hline Soybean cultivar Giza 35 + Mandarin & 3 August & 6 November & 27 July & 2 November \\
\hline Soybean cultivar Giza 82 + Mandarin & 3 August & 6 November & 27 July & 2 November \\
\hline Soybean cultivar Giza 111 + Mandarin & 1 September & 9 November & 24 August & 6 November \\
\hline \multicolumn{5}{|l|}{ Solid culture } \\
\hline Soybean cultivar Giza 21 & 3 August & --- & 27 July & --- \\
\hline Soybean cultivar Giza 22 & 1 September & --- & 24 August & --- \\
\hline Soybean cultivar Giza 35 & 3 August & --- & 27 July & --- \\
\hline Soybean cultivar Giza 82 & 3 August & --- & 27 July & --- \\
\hline Soybean cultivar Giza 111 & 1 September & --- & 24 August & --- \\
\hline Mandarin & --- & 6 November & --- & 2 November \\
\hline
\end{tabular}

\subsection{The Studied Traits}

\subsubsection{The Studied Mandarin Traits}

Total count of rhizobia in rhizosphere of mandarin roots (colony forming unit "cfu"/g soil) after 75 days from soybean sowing was performed Regional Center for Food \& Feed, Agricultural Research Center, Giza, Egypt. The culture medium was yeast extract mannitol agar, counting method was done by dilution plate count and incubation condition was $30^{\circ} \mathrm{C} / 2-3$ days. Methods of microbial analysis were described by Alexander and Clark [21]. At harvest, samples of ten fruits per tree were collected at harvesting date from plot to determine some fruit traits; fruit weight $(\mathrm{g})$, fruit volume $\left(\mathrm{cm}^{3}\right)$, total soluble solids (T.S.S. \%) of the fruit was determined by using Zeiss hand refractometer, fruit yield per tree $(\mathrm{kg})$ and fruit yield per ha (ton).

\subsubsection{The Studied Soybean Traits}

The traits on vegetative growth at 75 days of soybean sowing recorded on five plants from each plot were as follows: light intensity (lux) inside each canopy (at the middle of the plant and at the bottom of the plant at $20 \mathrm{~cm}$ from the soil surface) by Lux-meter apparatus at $12 \mathrm{~h}$ and expressed as percentage from light intensity measured above the plant. Leaf chlorophyll a and b contents $(\mathrm{mg} / \mathrm{g}$ leaves fresh weight) and plant dry weight ( $\mathrm{g}$ ) were recorded as analyzed by the General Organization for Agricultural Equalization Fund, ARC, Giza, Egypt, according to Holden [22]. At harvest, the following traits were measured on ten plants from each plot: plant height $(\mathrm{cm})$, number of branches per plant, number of pods per plant and seed yield per plant (g). Seed yield per ha (ton) were recorded 
on the basis of experimental sub plot area by harvesting all plants of each plot.

\subsubsection{Competitive Relationships}

1) Land equivalent ratio (LER):

LER is the ratio of area needed under sole cropping to one of interplanting at the same management level to produce an equivalent yield [23]. LER is calculated as follows: $\mathrm{LER}=\left(\mathrm{Y}_{\mathrm{ab}} / \mathrm{Y}_{\mathrm{aa}}\right)+\left(\mathrm{Y}_{\mathrm{ba}} / \mathrm{Y}_{\mathrm{bb}}\right)$, where $\mathrm{Y}_{\mathrm{aa}}=$ Pure stand yield of crop $\mathrm{a}$ (mandarin), $\mathrm{Y}_{\mathrm{bb}}=$ Pure stand yield of crop b (soybean), $\mathrm{Y}_{\mathrm{ab}}=$ Interplant yield of crop a (mandarin) and $\mathrm{Y}_{\mathrm{ba}}=$ Interplant yield of crop b (soybean). RY was calculated as follows: $R Y$ of mandarin $=\mathrm{Y}_{\mathrm{ab}} / \mathrm{Y}_{\mathrm{aa}}$; $\mathrm{RY}$ of soybean $=\mathrm{Y}_{\mathrm{ba}} / \mathrm{Y}_{\mathrm{b}}$, where $\mathrm{RY}$ of mandarin and RY of soybean are relative yields of mandarin and soybean, respectively.

\section{2) Land Equivalent coefficient (LEC):}

LEC is a measure of interaction concerned with the strength of relationship [24]. It is calculated as follows: $\mathrm{LEC}=\mathrm{La} \times \mathrm{Lb}$, where $\mathrm{La}=$ relative yield of crop $\mathrm{a}$ (mandarin) and $\mathrm{Lb}=$ relative yield of crop $\mathrm{b}$ (soybean).

\subsubsection{Financial Return (US\$ per ha)}

It was calculated as a difference between total net returns from interplanting and solid cultures. Soybean seeds and mandarin fruits prices presented by market price (2018) were used. Total return per ha was calculated by plus income of mandarin fruits per ha (US\$) with income of soybean seeds per ha (US\$). Market prices of crops are US\$194 per ton for mandarin fruits and US\$ 450 per ton for soybean seeds. Monetary Advantage Index (MAI): it suggests that the economic assessment should be in terms of the value of land saved; this could probably be most assessed on the basis of the rentable value of this land. MAI was calculated according to the formula, suggested by Willey [25]. MAI = [Value of combined intercrops $\times($ LER -1$)] /$ LER.

\subsection{Statistical Analysis}

Analysis of variance of the obtained results of each season was performed. The measured variables were analyzed by ANOVA using MSTATC statistical package [26]. Mean comparisons were performed using the least significant differences (L.S.D) test with a significance level of 5\% [27].

\section{Results and Discussion}

\subsection{The Four Years Old of Mandarin Trees}

\subsubsection{Total Count of Rhizobia in Rhizosphere of Mandarin Roots after 75} Days from Soybean Sowing

Total rhizobia count in rhizosphere of mandarin trees after 75 days from soybean sowing was affected significantly by interplanting soybean cultivars with mandarin trees in both seasons (Table 5). Growing soybean cv. Giza 22 with mandarin trees was leading in this respect and increased significantly the total a count of rhizobia in root rhizosphere of mandarin trees, following by soybean 
Table 5. Total count of rhizobia in rhizosphere of mandarin roots under intercropping and solid cultures after 75 days from soybean sowing in both seasons.

\begin{tabular}{ccccc}
\hline \multirow{2}{*}{ Treatments } & \multicolumn{4}{r}{ Total count of rhizobia in rhizosphere of mandarin roots (cfu/g soil) } \\
\cline { 2 - 5 } & \multicolumn{2}{r}{ First season (2018) } & \multicolumn{2}{r}{ Second season (2019) } \\
\cline { 2 - 5 } & Original data & Transformed data & Original data & Transformed data \\
\hline Mandarin + Giza 21 & $2.3 \times 10^{6}$ & 6.36 & $4.1 \times 10^{6}$ & 6.61 \\
Mandarin + Giza 22 & $3.7 \times 10^{6}$ & 6.56 & $6.9 \times 10^{6}$ & 6.83 \\
Mandarin + Giza 35 & $2.5 \times 10^{6}$ & 6.39 & $4.6 \times 10^{6}$ & 6.66 \\
Mandarin + Giza 82 & $2.5 \times 10^{6}$ & 6.39 & $4.3 \times 10^{6}$ & 6.63 \\
Mandarin + Giza 111 & $3.3 \times 10^{6}$ & 6.51 & $6.0 \times 10^{6}$ & 6.77 \\
Mandarin solid planting & $1.7 \times 10^{6}$ & 6.23 & $3.5 \times 10^{6}$ & 6.54 \\
L.S.D. at 5\% & --- & 0.05 & --- & 0.06 \\
\hline
\end{tabular}

cv. Giza 111 than that of solid mandarin in both seasons. In general, the results showed the confirmation of the benefit of growing leguminous crops with mandarin trees to increase the number of microbes significantly in the rhizosphere of tree roots and the consequently increase atmospheric $\mathrm{N}$ fixation.

Consequently, it seems that the studied soybean cultivars had different biological $\mathrm{N}$ fixation abilities when interplanted with mandarin trees, which reflected on differences in total rhizobia count of mandarin trees rhizosphere than those of mandarin solid planting. These results could be attributed to canopy structure of soybean cultivar Giza 22 was more compatible with shading effects of mandarin trees than the other soybean cultivars. Canopy structure of soybean cultivar Giza 22 had narrow leaves [28] than the other cultivars, which reflected positively on light penetration and transmission within the other parts of plant and thereby higher biological $\mathrm{N}$ fixation ability under interplanting conditions. With respect to soybean cultivar Giza 111, it had higher leaves dry weight per plant (late maturing cultivar) than the other soybean cultivars [29], probably resulted in higher biological $\mathrm{N}$ fixation ability during vegetative growth and development. Accordingly, it is expected that nodules ability in roots of soybean cultivar Giza 22 and Giza 111 had a longer duration than those of the other soybean cultivars (Table 3) led to differences in their harvested dates (Table 4). At the time of pod fill, nodules on annual legumes generally lose their ability to fix $\mathrm{N}$, because the plant feeds the developing seed rather than the nodule [30].

\subsubsection{Mandarin Fruit Yield and Its Attributes}

All the studied mandarin traits were affected significantly by interplanting soybean cultivars with mandarin trees in both seasons (Table 6). Interplanting soybean cultivar Giza 22 or Giza 111 with mandarin trees increased significantly fruit weight and volume, T.S.S., fruit yields per tree and per ha compared with the other treatments in both seasons. These results may be attributed to higher atmospheric $\mathrm{N}$ fixing bacteria (rhizobia) in thizosphere of mandarin roots by 
Table 6. Effect of interplanting some soybean cultivars with mandarin trees on mandarin fruit yield and its attributes in both seasons.

\begin{tabular}{cccccc}
\hline Cropping system & $\begin{array}{c}\text { Fruit } \\
\text { weight }(\mathrm{g})\end{array}$ & $\begin{array}{c}\text { Fruit } \\
\text { volume }\left(\mathrm{cm}^{3}\right)\end{array}$ & $\begin{array}{c}\text { T.S.S. } \\
(\%)\end{array}$ & $\begin{array}{c}\text { Fruit } \\
\text { yield/tree (kg) }\end{array}$ & $\begin{array}{c}\text { Fruit } \\
\text { yield/ha (ton) }\end{array}$ \\
\cline { 2 - 6 } & \multicolumn{5}{c}{ First season (2018) } \\
\hline Mandarin + Giza 21 & 44.71 & 16.23 & 12.60 & 10.76 & 7.91 \\
Mandarin + Giza 22 & 45.97 & 16.64 & 12.70 & 11.54 & 8.43 \\
Mandarin + Giza 35 & 44.50 & 16.11 & 12.50 & 10.46 & 7.82 \\
Mandarin + Giza 82 & 44.93 & 16.10 & 12.50 & 10.67 & 7.89 \\
Mandarin + Giza 111 & 45.43 & 16.58 & 12.70 & 11.23 & 8.25 \\
Mandarin solid culture & 44.65 & 16.25 & 12.50 & 10.61 & 7.82 \\
L.S.D. at 5\% & $\mathbf{0 . 7 3}$ & $\mathbf{0 . 3 2}$ & $\mathbf{0 . 1 1}$ & $\mathbf{0 . 4 3}$ & $\mathbf{0 . 2 5}$ \\
Cropping system & & & Second season $(2019)$ & \\
Mandarin + Giza 21 & 45.31 & 16.43 & 12.70 & 11.37 & 8.83 \\
Mandarin + Giza 22 & 46.51 & 16.68 & 12.90 & 12.38 & 9.45 \\
Mandarin + Giza 35 & 45.20 & 16.22 & 12.60 & 11.45 & 8.99 \\
Mandarin + Giza 82 & 45.76 & 16.30 & 12.60 & 11.11 & 8.70 \\
Mandarin + Giza 111 & 46.05 & 16.56 & 12.90 & 12.03 & 9.22 \\
Mandarin solid culture & 45.46 & 16.37 & 12.60 & 11.21 & 8.78 \\
L.S.D. at 5\% & $\mathbf{0 . 5 7}$ & $\mathbf{0 . 1 7}$ & $\mathbf{0 . 2 2}$ & $\mathbf{0 . 5 7}$ & $\mathbf{0 . 3 1}$ \\
\hline
\end{tabular}

interplanting soybean with mandarin that reduced soil $\mathrm{pH}$ and thereby increased availability of other elements in the soil. According to Lovatt et al. [31], higher contents of $\mathrm{N}$ in the buds and leaves increased the number of flowers per tree, which explained the increase in fruit yield per tree. It is known that, legumes played a major role in the farming system [32]. Total soil $\mathrm{N}$ was enhanced, especially legumes in sole or intercropping culture because of symbiotic atmospheric $\mathrm{N}$ fixation [33].

So, it is expected that total soil $\mathrm{N}$ was been enhanced in rhizosphere of mandarin roots by interplanting with soybean cultivar Giza 22 or Giza 111 compared with the others where the populations of rhizobia were considered as a biological pool influencing soil nutrient dynamics. Phosphorus improved growth, nutritional status of trees, yield and fruit quality of citrus, macronutrient in nutrition of citrus trees regulated large-scale production of high fruit quality [34]. Particularly, Postgate [35] showed that the fixed $\mathrm{N}$ is available to other plants and helps to fertilize the soil. On the other hand, rhizobia promoted plant growth by solubilization of mineral phosphates and other nutrients [36]. N fixing bacteria, besides fixing $\mathrm{N}$, solubilized phosphorus due to production of organic acids and enzymes. The indole-3-acetamide (IAM) pathway produced high amounts of $\mathrm{N}$ and indole acetic acid that could play a positive effect on fruit weight and volume. The physiological role of various endogenous plant growth substances re- 
gulated the growth, development, maturity of fruit naturally. Thus, it is expected that other soil nutrients such as zinc facilitated the recovery of the entire leaf to a green color, which delayed mandarin fruit maturity. These results are in harmony with those obtained by Srivastava et al. [7].

\subsection{Soybean Plant}

\subsubsection{Vegetative Growth Parameters after 75 Days from Soybean Sowing \\ 1) Cropping Systems}

Percentages of light intensity at the middle and bottom of the plant, chlorophylls a and b, as well as, plant dry weight after 75 days from soybean sowing were affected significantly by the cropping systems in both seasons (Table 7). Interplanting soybean with mandarin trees decreased light intensity at the middle and bottom of the plant, chlorophylls a and b, as well as plant dry weight after 75 days from soybean sowing compared with those of solid one in both seasons. Shading of mandarin trees decreased light intensity at the middle of the plant by $22.95 \%$ and $22.06 \%$ in the first and second seasons, respectively, and at bottom of the plant by $37.70 \%$ and $43.99 \%$ in the first and second season, respectively, compared with soybean solid culture. Also, shading of mandarin trees decreased chlorophylls a and b by $40.09 \%$ and $8.64 \%$ in the first season and $38.11 \%$ and $6.93 \%$ in the second season, respectively, compared with soybean solid culture. Moreover, shading of mandarin trees decreased plant dry weight by $18.62 \%$ and $18.23 \%$ in the first and second seasons, respectively.

It is observed that interplanting soybean with mandarin trees decreased light penetration and transmission within soybean leaves and consequently negative effect on dry matter accumulation of soybean components during different stages of soybean. It is known that plant dry matter production often shows a positive correlation with the amount of intercepted radiation by crops in intercropping system [37]. Low light levels available for shaded soybean plants might have caused a restriction of their genetic potential resulting in the modification of their growth pattern [38].

Table 7. Effect of cropping systems, soybean cultivars and their interaction on some vegetative growth parameters after 75 days from soybean sowing in both seasons.

\begin{tabular}{|c|c|c|c|c|c|c|}
\hline \multirow{3}{*}{$\begin{array}{l}\text { Cropping } \\
\text { systems }\end{array}$} & \multirow{3}{*}{ Soybean cultivars } & \multicolumn{2}{|c|}{$\begin{array}{l}\text { Percentage of light } \\
\text { intensity (lux) at }\end{array}$} & \multirow{2}{*}{$\begin{array}{c}\text { Chlorophyll a } \\
\text { (mg/g leaves fresh } \\
\text { weight) }\end{array}$} & \multirow{2}{*}{$\begin{array}{c}\text { Chlorophyll b } \\
\text { (mg/g leaves fresh } \\
\text { weight) }\end{array}$} & \multirow{2}{*}{$\begin{array}{c}\text { Plant dry weight } \\
\text { (g) }\end{array}$} \\
\hline & & $\begin{array}{c}\text { Middle of the } \\
\text { plant }\end{array}$ & $\begin{array}{c}\text { Bottom of the } \\
\text { plant }\end{array}$ & & & \\
\hline & & \multicolumn{5}{|c|}{ First season (2018) } \\
\hline \multirow{4}{*}{ Interplanting } & Giza 21 & 8.03 & 3.32 & 0.98 & 0.62 & 46.17 \\
\hline & Giza 22 & 8.20 & 3.51 & 1.34 & 0.78 & 83.19 \\
\hline & Giza 35 & 8.12 & 3.26 & 1.18 & 0.70 & 50.56 \\
\hline & Giza 82 & 8.16 & 3.29 & 1.41 & 0.90 & 55.05 \\
\hline
\end{tabular}




\section{Continued}

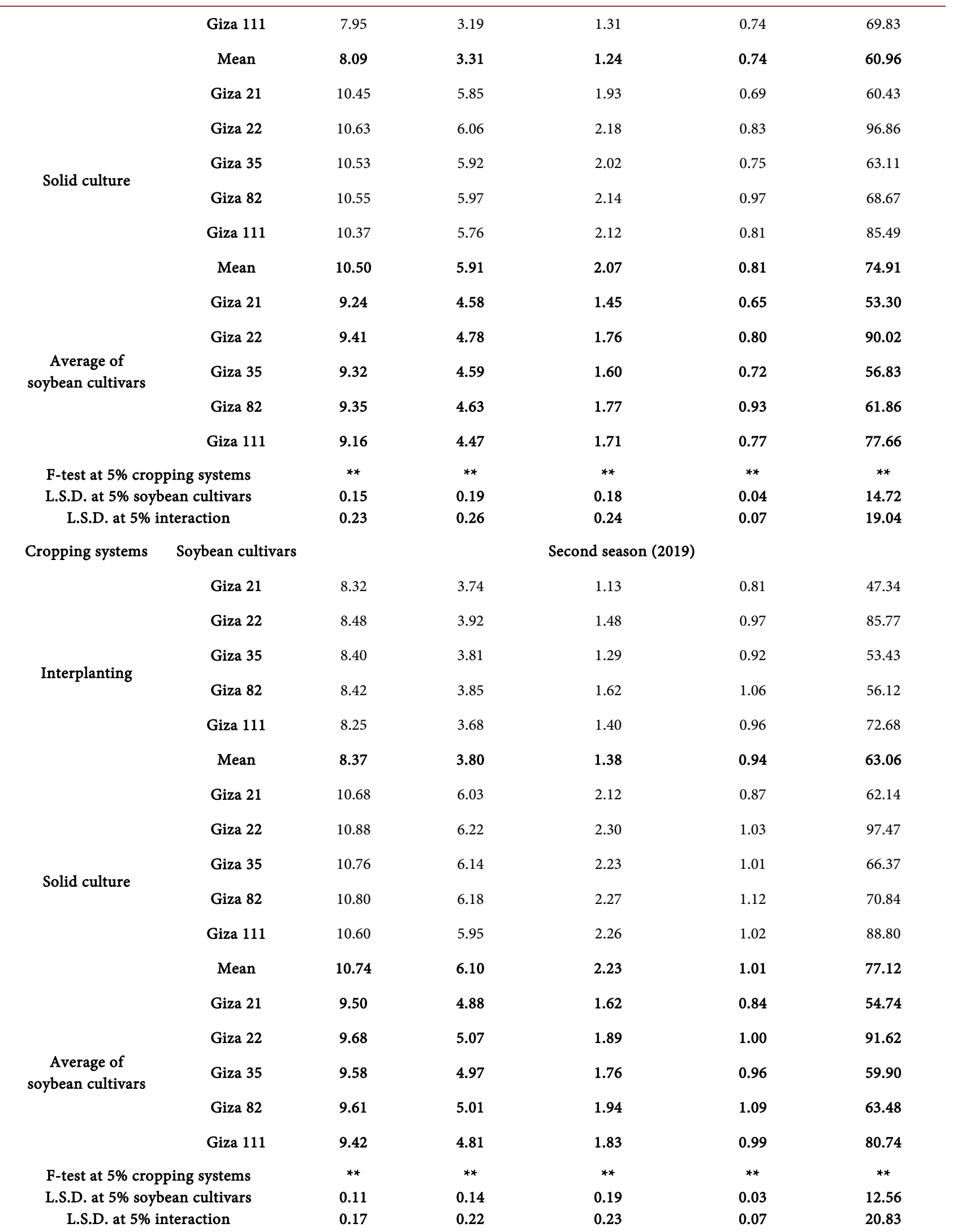




\section{2) Soybean cultivars}

Percentages of light intensity at the middle and bottom of the plant, chlorophylls a and b, as well as, plant dry weight after 75 days from soybean sowing were different significantly among soybean cultivars in both seasons (Table 7). Soybean cultivars Giza 22 and Giza 82 had higher light intensity at the middle and bottom of the plant, as well as chlorophyll a, meanwhile soybean cultivars Giza 22 and Giza 111 had higher plant dry weight than the other soybean cultivars after 75 days from soybean sowing in both seasons. These results probably attributed to there were differences among all the studied soybean cultivars in their genetic makeup that translated into different canopies structures. Soybean cultivar Giza 21 had the tallest plants [39] and reflected negatively on light penetration and transmission within soybean canopy which led to lower chlorophylls $a$ and $b$, as well as dry matter accumulation in the other parts of soybean plant than the other soybean cultivars. Meanwhile, soybean cultivars Giza 22 and Giza 111 had some leaves characteristics [28] that reflected on higher dry matter accumulation in the other parts of soybean plant than the other soybean cultivars (Table 7). It is worthy to note that maturity group of all the studied soybean cultivars played a major role in dry matter accumulation, where the early maturing cultivars Giza 35 and Giza 82 gave lower dry matter accumulation as a result of completed their life cycle quickly than the late maturing cultivars (Table 3 ).

\section{3) The interaction between cropping systems and soybean cultivars}

Percentages of light intensity at the middle and bottom of the plant, chlorophylls a and $b$, as well as plant dry weight after 75 days from soybean sowing were affected significantly by the interaction between cropping systems and soybean cultivars in both seasons (Table 7). Interplanting all the studied soybean cultivars with mandarin trees had lower all the studied parameters after 75 days from soybean sowing compared with those of solid one in both seasons. With respect to soybean cultivars, soybean cultivar Giza 22 and Giza 82 had higher light intensity at middle and bottom of the plant, as well as chlorophyll a than the other soybean cultivars under interplanting and solid plantings in both seasons. Meanwhile, soybean cultivar Giza 22 and Giza 111 had higher plant dry weight than the other soybean cultivars under interplanting and solid plantings in both seasons. Although soybean cultivars Giza 22 and Giza 111 belong to the same maturity group (Table 3), BNF ability was similar between them (Table 5). Additionally, leaves characteristics were different between soybean cultivars Giza 22 and Giza 111 according to Metwally et al. [28] and Abdel-Galil et al. [29]. These results suggest that canopies architectures of soybean cultivars Giza 22 and Giza 111 had higher ability to tolerate adverse effects of mandarin through leaves characteristics and BNF ability, which reflected on higher plant dry weight than the other soybean cultivars. These data reveal that there was a significant effect of cropping systems $\mathrm{x}$ soybean cultivars on light intensity at the middle and bottom of the plant, chlorophylls a and b, as well as plant dry weight after 75 days from soybean sowing. 


\subsubsection{Seed Yield and Its Attributes}

\section{1) Cropping systems}

Plant height, numbers of branches and pods per plant, seed yields per plant and per ha were affected significantly by the cropping systems in both seasons (Table 8). Interplanting soybean with mandarin trees increased plant height but it decreased numbers of branches and pods per plant, seed yields per plant and per ha compared with those of solid one in both seasons. Interplanting soybean with mandarin trees increased plant height by $12.04 \%$ and $12.37 \%$ in the first and second seasons, respectively, compared with soybean solid planting.

It is obvious that interplanting formed unfavorable conditions for soybean plants which reflected on the severe decrease in intercepted light intensity by soybean canopy during soybean growth (Table 7) and consequently more amounts of plant hormones. So, the observed response in plant height of soybean may be primarily attributed to an increase of internode elongation of shaded soybean plant as a result of increasing plant hormones [29]. It is important to note that interplanting soybean with mandarin trees increased shading intensity around soybean canopy and consequently lower dry matter accumulation in the other parts of soybean plant. According to Board and Harville [40], pod number per plant as the yield component was most influenced by changing cultural and environmental conditions. It is known that shading during early flowering stage decreased assimilates availability to the developing reproductive structures, and thereby pod number at harvest [41]. These results are in accordance with those obtained by Abdel-Wahab and Abd El-Rahman [42] who showed that intercropping decreased the number of pods per plant.

Table 8. Effect of cropping systems, soybean cultivars and their interaction on soybean seed yield and its attributes in both seasons.

\begin{tabular}{|c|c|c|c|c|c|c|}
\hline \multirow{2}{*}{$\begin{array}{l}\text { Cropping } \\
\text { systems }\end{array}$} & \multirow{2}{*}{$\begin{array}{l}\text { Soybean } \\
\text { cultivars }\end{array}$} & $\begin{array}{l}\text { Plant height } \\
\quad(\mathrm{cm})\end{array}$ & $\begin{array}{c}\text { Number of branches } \\
\text { per plant }\end{array}$ & $\begin{array}{l}\text { Number of pods } \\
\text { per plant }\end{array}$ & $\begin{array}{l}\text { Seed yield per } \\
\text { plant }(\mathrm{g})\end{array}$ & $\begin{array}{l}\text { Seed yield per } \\
\text { ha (ton) }\end{array}$ \\
\hline & & \multicolumn{5}{|c|}{ First season (2018) } \\
\hline \multirow{6}{*}{ Interplanting } & Giza 21 & 110.62 & 2.30 & 37.25 & 8.54 & 1.24 \\
\hline & Giza 22 & 102.29 & 3.32 & 37.75 & 9.52 & 1.49 \\
\hline & Giza 35 & 108.86 & 2.63 & 37.51 & 9.03 & 1.36 \\
\hline & Giza 82 & 103.23 & 3.42 & 37.56 & 9.21 & 1.37 \\
\hline & Giza 111 & 105.40 & 2.91 & 37.91 & 9.77 & 1.44 \\
\hline & Mean & 106.08 & 2.91 & 37.59 & 9.21 & 1.38 \\
\hline \multirow{6}{*}{ Solid culture } & Giza 21 & 98.82 & 4.04 & 48.71 & 10.21 & 3.12 \\
\hline & Giza 22 & 91.87 & 5.53 & 49.09 & 11.39 & 3.50 \\
\hline & Giza 35 & 96.07 & 4.33 & 48.91 & 10.87 & 3.38 \\
\hline & Giza 82 & 92.21 & 5.65 & 48.92 & 11.08 & 3.41 \\
\hline & Giza 111 & 94.44 & 4.82 & 49.29 & 11.67 & 3.60 \\
\hline & Mean & 94.68 & 4.87 & 48.98 & 11.04 & 3.40 \\
\hline
\end{tabular}




\begin{tabular}{|c|c|c|c|c|c|c|}
\hline & Giza 21 & 104.72 & 3.17 & 42.98 & 9.37 & 2.18 \\
\hline \multirow{4}{*}{$\begin{array}{l}\text { Average of } \\
\text { soybean } \\
\text { cultivars }\end{array}$} & Giza 22 & 97.08 & 4.42 & 43.42 & 10.45 & 2.49 \\
\hline & Giza 35 & 102.46 & 3.48 & 43.21 & 9.95 & 2.37 \\
\hline & Giza 82 & 97.72 & 4.53 & 43.24 & 10.14 & 2.39 \\
\hline & Giza 111 & 99.92 & 3.86 & 43.60 & 10.70 & 2.52 \\
\hline \multicolumn{2}{|c|}{ F-test at $5 \%$ cropping systems } & $* *$ & $* *$ & ** & ** & $* *$ \\
\hline \multicolumn{2}{|c|}{ L.S.D. at $5 \%$ soybean cultivars } & 1.64 & N.S. & 0.20 & 0.41 & 0.11 \\
\hline \multicolumn{2}{|c|}{ L.S.D. at $5 \%$ interaction } & 1.73 & 3.02 & 0.35 & 0.48 & 0.17 \\
\hline \multirow[t]{3}{*}{$\begin{array}{l}\text { Cropping } \\
\text { systems }\end{array}$} & $\begin{array}{l}\text { Soybean } \\
\text { cultivars }\end{array}$ & \multicolumn{5}{|c|}{ Second season (2019) } \\
\hline & Giza 21 & 108.56 & 2.67 & 39.93 & 9.66 & 1.46 \\
\hline & Giza 22 & 99.82 & 3.71 & 40.54 & 10.60 & 1.66 \\
\hline \multirow{4}{*}{ Interplanting } & Giza 35 & 106.11 & 2.96 & 40.08 & 10.15 & 1.53 \\
\hline & Giza 82 & 100.12 & 3.87 & 40.19 & 10.34 & 1.57 \\
\hline & Giza 111 & 103.33 & 3.23 & 40.62 & 10.90 & 1.66 \\
\hline & Mean & 103.58 & 3.28 & 40.27 & 10.33 & 1.57 \\
\hline \multirow{6}{*}{ Solid culture } & Giza 21 & 94.32 & 4.41 & 49.78 & 11.29 & 3.48 \\
\hline & Giza 22 & 90.03 & 5.80 & 50.11 & 12.51 & 3.86 \\
\hline & Giza 35 & 93.21 & 4.68 & 49.91 & 11.99 & 3.76 \\
\hline & Giza 82 & 90.81 & 5.96 & 50.02 & 12.16 & 3.77 \\
\hline & Giza 111 & 92.36 & 5.12 & 50.41 & 12.74 & 3.92 \\
\hline & Mean & 92.14 & 5.19 & 50.04 & 12.13 & 3.75 \\
\hline \multirow{5}{*}{$\begin{array}{l}\text { Average of } \\
\text { soybean } \\
\text { cultivars }\end{array}$} & Giza 21 & 101.44 & 3.54 & 44.85 & 10.47 & 2.47 \\
\hline & Giza 22 & 94.92 & 4.75 & 45.32 & 11.55 & 2.76 \\
\hline & Giza 35 & 99.66 & 3.82 & 44.99 & 11.07 & 2.64 \\
\hline & Giza 82 & 95.46 & 4.91 & 45.10 & 11.25 & 2.67 \\
\hline & Giza 111 & 97.84 & 4.17 & 45.51 & 11.82 & 2.79 \\
\hline \multicolumn{2}{|c|}{ F-test at $5 \%$ cropping systems } & ** & ** & $* *$ & ** & $* *$ \\
\hline \multicolumn{2}{|c|}{ L.S.D. at $5 \%$ soybean cultivars } & 1.76 & N.S. & 0.27 & 0.45 & 0.04 \\
\hline \multicolumn{2}{|c|}{ L.S.D. at $5 \%$ interaction } & N.S. & 2.94 & 0.39 & 0.54 & 0.08 \\
\hline
\end{tabular}

Also, shading of mandarin trees decreased seed yield per plant by $16.57 \%$ and $14.83 \%$ in the first and second season, respectively, seed yield per ha by $59.41 \%$ and $58.13 \%$ in the first and second seasons, respectively compared with soybean solid culture. This may be due to the adverse effects of interplanting increased inter-specific competition between mandarin and soybean plants for basic growth resources, which reflected negatively on soybean productivity per unit area compared with soybean solid culture. These results are in the same context 
of those obtained by Eweida et al. [43], Egbe [44] and Metwally et al. [45] who investigated that intercropped soybean produced lower seed yield than their sole crop counterparts.

\section{2) Soybean cultivars}

Soybean cultivars differed significantly for plant height, seed yields per plant and per ha, meanwhile numbers of branches and pods per plant were not different among soybean cultivars in both seasons (Table 8). Soybean cultivar Giza 21 had the tallest plants, meanwhile soybean cultivars Giza 22 and Giza 82 gave shorter plants than the other soybean cultivars in both seasons. Also, soybean cultivars Giza 111 and Giza 22 gave a higher number of pods per plant, seed yields per plant and per ha followed by soybean cultivar Giza 82 than the other soybean cultivars in both seasons. These results were attributed to soybean cultivars Giza 22 and Giza 82 had higher plant dry weight after 75 days from soybean sowing than the other soybean cultivars (Table 7) which reflected positively yield attributes of soybean. With respect to soybean cultivar Giza 82, it seems that maturity group of plants of this cultivar played a major role in utilizing from available growth resources during the developing reproductive stages, which reflected positively on their yielding ability. These results reveal that the genetic potential of the studied cultivars interacted with available basic growth resources through duration of vegetative and reproductive stages that translated finally into the economic yield.

\section{3) The interaction between cropping systems and soybean cultivars}

The interaction between cropping systems and soybean cultivars affected significantly all the studied traits of soybean in both seasons, except plant height in the second season (Table 8). Soybean cultivar Giza 21 produced the tallest plants, whereas, soybean cultivar Giza 22 gave shorter plants under interplanting culture in both seasons. Moreover, soybean cultivar Giza 111 recorded a higher number of pods, seed yield per plant, as well as seed yield per ha followed by soybean cultivars Giza 22 and Giza 82, respectively. Whereas, Giza 21 gave lower values of the same characters in both seasons. These results were due to genetic makeup of soybean cultivars Giza 111 and Giza 22 that translated into suitable some morphological and physiological characters responded positively to shading effects of mandarin tree, which reflected positively on plant dry weight after 75 days from soybean sowing (Table 7).

It is likely that canopies architectures of soybean cultivars Giza 111 and Giza 22 were more compatible with adverse effects of mandarin shading, which reflected positively on their productivity per unit area. With regard to soybean cultivars Giza 82, it had self regulation mechanism of redistributing the available assimilates to components, in an attempt to maintain or improve yield under high shading intensity [42]. These data show that each of these two factors acts dependently on all the studied traits of soybean. These results are in accordance with those observed by Gadallah and Selim [45] and Metwally et al. [46] who found that soybean cultivars responded deferentially to the cropping system. 


\subsection{Competitive Relationships}

\subsubsection{Land Equivalent Ratio (LER)}

The values of land equivalent ratio (LER) were estimated by using data of recommended solid cultures of both crops. LER of more than 1.00 indicates yield advantage, equal to 1.00 indicates no gain or no loss and less than 1.00 indicates yield loss [47]. It can be used both for replacement and additives series of interplanting. The results obtained strongly coincided with the definition of LER. Land equivalent ratio values were greater than one for all soybean cultivars under interplanting with mandarin trees in both seasons (Table 9 and Figure 1).

Land equivalent ratio ranged from 1.40 by interplanting soybean cultivars Giza 21, Giza 35 and Giza 82 with mandarin trees to 1.50 by interplanting soybean cultivar Giza 22 with mandarin trees in the first season. Also, LER ranged from 1.40 by interplanting soybean cultivar Giza 35 with mandarin trees to 1.50 by interplanting soybean cultivar Giza 22 with mandarin trees in the second one. Growing soybean cultivar Giza 111 with mandarin trees came in the second rank for LER in both seasons. LER of 1.50 indicates that the planted area to solid cultures would need to be $50 \%$ greater than the planted area to interplant to produce the same combined yields (i.e. $50 \%$ more land would be required as a solid crop to produce the same yield as interplanting).

The advantage of the highest LER by interplanting soybean cultivars Giza 22 and Giza 111 with mandarin trees probably due to the late maturing cultivar Giza

Table 9. Relative yields (RY) of soybean and mandarin, LER and LEC of interplanting some soybean cultivars with mandarin in both seasons.

\begin{tabular}{ccccc}
\hline & RY of mandarin & RY of soybean & LER & LEC \\
\cline { 2 - 5 } Cropping system & \multicolumn{4}{c}{ First season (2018) } \\
\hline Mandarin + Giza 21 & 1.01 & 0.39 & 1.40 & 0.39 \\
Mandarin + Giza 22 & 1.07 & 0.43 & 1.50 & 0.46 \\
Mandarin + Giza 35 & 1.00 & 0.40 & 1.40 & 0.40 \\
Mandarin + Giza 82 & 1.00 & 0.40 & 1.40 & 0.40 \\
Mandarin + Giza 111 & 1.05 & 0.40 & 1.45 & 0.42 \\
Solid culture & 1.00 & 1.00 & 1.00 & 1.00 \\
Cropping system & & Second season & $(2019)$ & \\
Mandarin + Giza 21 & 1.00 & 0.42 & 1.42 & 0.42 \\
Mandarin + Giza 22 & 1.07 & 0.43 & 1.50 & 0.46 \\
Mandarin + Giza 35 & 0.99 & 0.41 & 1.40 & 0.40 \\
Mandarin + Giza 82 & 1.02 & 0.42 & 1.44 & 0.42 \\
Mandarin + Giza 111 & 1.05 & 0.42 & 1.47 & 0.44 \\
Solid culture & 1.00 & 1.00 & 1.00 & 1.00 \\
\hline
\end{tabular}



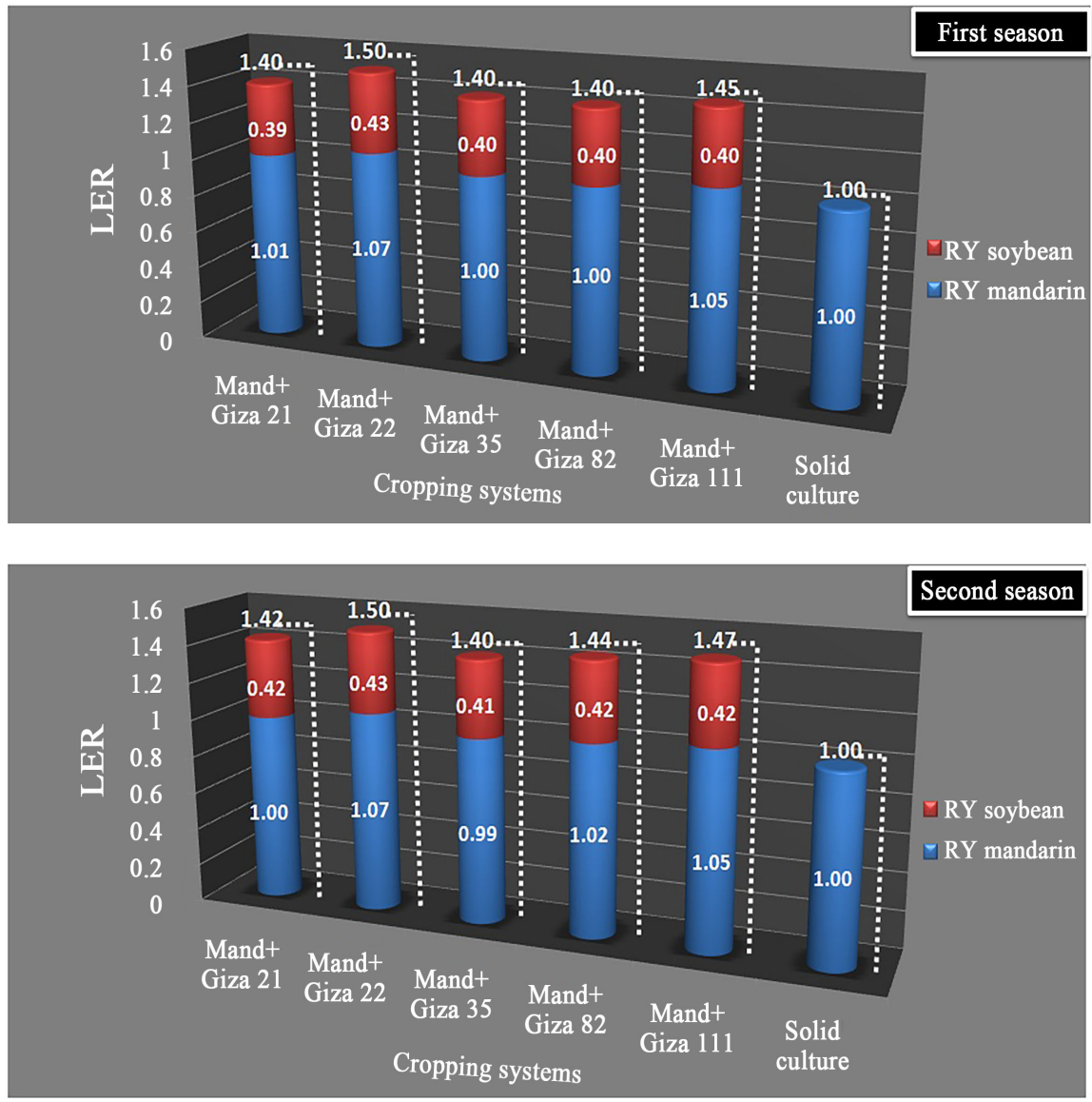

Figure 1. Relative yields (RY) of soybean and mandarin and LER of interplanting some soybean cultivars with mandarin in both seasons.

22 had the longest period of vegetative growth during available climatic and edaphic conditions which reflected positively on RY of both crops.

\subsubsection{Land Equivalent Coefficient (LEC)}

Land equivalent coefficient (LEC) is a measure of interaction concerned with the strength of relationship. Land equivalent coefficient (LEC) is used for a twocrop mixture the minimum expected productivity coefficient (PC) is 25 per cent, that is, a yield advantage is obtained if LEC value was exceeded 0.25 . LEC values were greater than 0.25 in all the studied treatments (Table 9 and Figure 2). LEC ranged from 0.39 by interplanting soybean cultivar Giza 21 with mandarin trees to 0.46 by interplanting soybean cultivar Giza 22 with mandarin trees in the first season. Also, LEC ranged from 0.40 by interplanting soybean cultivar Giza 21 with mandarin trees to 0.46 by interplanting soybean cultivar Giza 22 with mandarin trees in the second one. Growing soybean cultivar Giza 111 with mandarin trees came in the second rank for LEC in both seasons. The advantage of the highest LEC by interplanting soybean cultivar Giza 22 with mandarin trees could be due competitive pressure for basic growth resources between the intercrops was lower compared with the other treatments. 


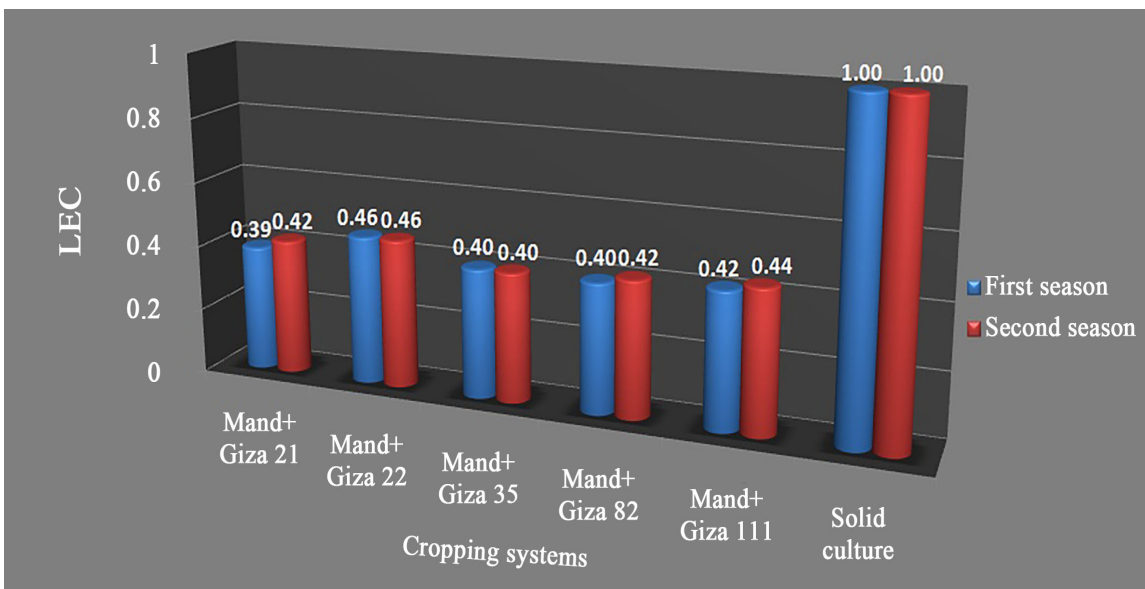

Figure 2. LEC of interplanting some soybean cultivars with mandarin in both seasons.

\subsection{Financial Return}

\subsubsection{Total Return}

The financial return of interplanting soybean with mandarin trees compared with solid culture of mandarin is shown in Table 10 (Figure 3 and Figure 4). Total return of interplanting soybean with mandarin trees varied between treatments from US\$2092 to 2305 per ha compared with solid culture of mandarin (US\$ 1517 per ha) in the first season (Figure 3).

Also, total return of interplanting soybean with mandarin trees varied between treatments from US\$2370 to 2580 per ha compared with solid culture of mandarin (US\$ 1703 per ha) in the second one (Figure 3). Growing soybean cultivar Giza 22 with mandarin trees achieved the highest total return per ha compared with the other treatments in both seasons. Growing soybean cultivar Giza 111 with mandarin trees came in the second rank for total return per ha in both seasons. These results reveal that interplanting soybean cultivar Giza 22 or Giza 111 with mandarin trees is more profitable than solid culture of mandarin for Egyptian farmers. These results are in agreement with Lachungpa [6].

\subsubsection{Monetary Advantage Index (MAI)}

The economic performance of the interplanting was evaluated to determine if soybean and mandarin combined yields are high enough for the farmers to adopt this system. Interplanting soybean cultivar Giza 22 with mandarin trees recorded the highest MAI values compared with the other treatments in both seasons (Table 10 and Figure 4). Growing soybean cultivar Giza 111 with mandarin trees came in the second rank for MAI in both seasons. In addition, interplanting soybean cv. Giza 21 with mandarin trees recorded the lowest values of MAI (US\$ 597 and 700 in the first and second seasons, respectively). Differences between the highest and the lowest values were US\$171 in the first season and US $\$ 182$ in the second one. Growing soybean cvs. Giza 22 and Giza 111 with mandarin trees was mainly influenced by the complementary effects between the both species which resulted in high MAI and could be recommended. 
Table 10. Financial return of intercropping some soybean cultivars with mandarin trees in both seasons.

\begin{tabular}{ccccc}
\hline Cropping system & $\begin{array}{c}\text { Income of } \\
\text { mandarin (US\$/ha) }\end{array}$ & $\begin{array}{c}\text { Income of } \\
\text { soybean (US\$/ha) }\end{array}$ & $\begin{array}{c}\text { Total return } \\
\text { (US\$/ha) }\end{array}$ & MAI \\
\cline { 2 - 5 } & 1534 & First season (2018) \\
\hline Mandarin + Giza 21 & 1635 & 558 & 2092 & 597 \\
Mandarin + Giza 22 & 1530 & 670 & 2305 & 768 \\
Mandarin + Giza 35 & 1517 & 612 & 2142 & 612 \\
Mandarin + Giza 82 & 1600 & 616 & 2133 & 609 \\
Mandarin + Giza 111 & 1517 & 648 & 2248 & 697 \\
Solid culture of mandarin & 1713 & --- & 1517 & --- \\
Cropping system & 1833 & 657 & 2370 & 700 \\
Mandarin + Giza 21 & 1687 & 747 & 2580 & 860 \\
Mandarin + Giza 22 & 1744 & 688 & 2375 & 678 \\
Mandarin + Giza 35 & 1788 & 706 & 2450 & 748 \\
Mandarin + Giza 82 & 1703 & 747 & 2535 & 810 \\
Mandarin + Giza 111 & & --- & 1703 & --- \\
\hline Solid culture of mandarin & & Second season (2019) & & \\
\hline
\end{tabular}

Market prices of crops: US\$ 194 per ton for mandarin fruits and US\$ 450 per ton for soybean seeds.
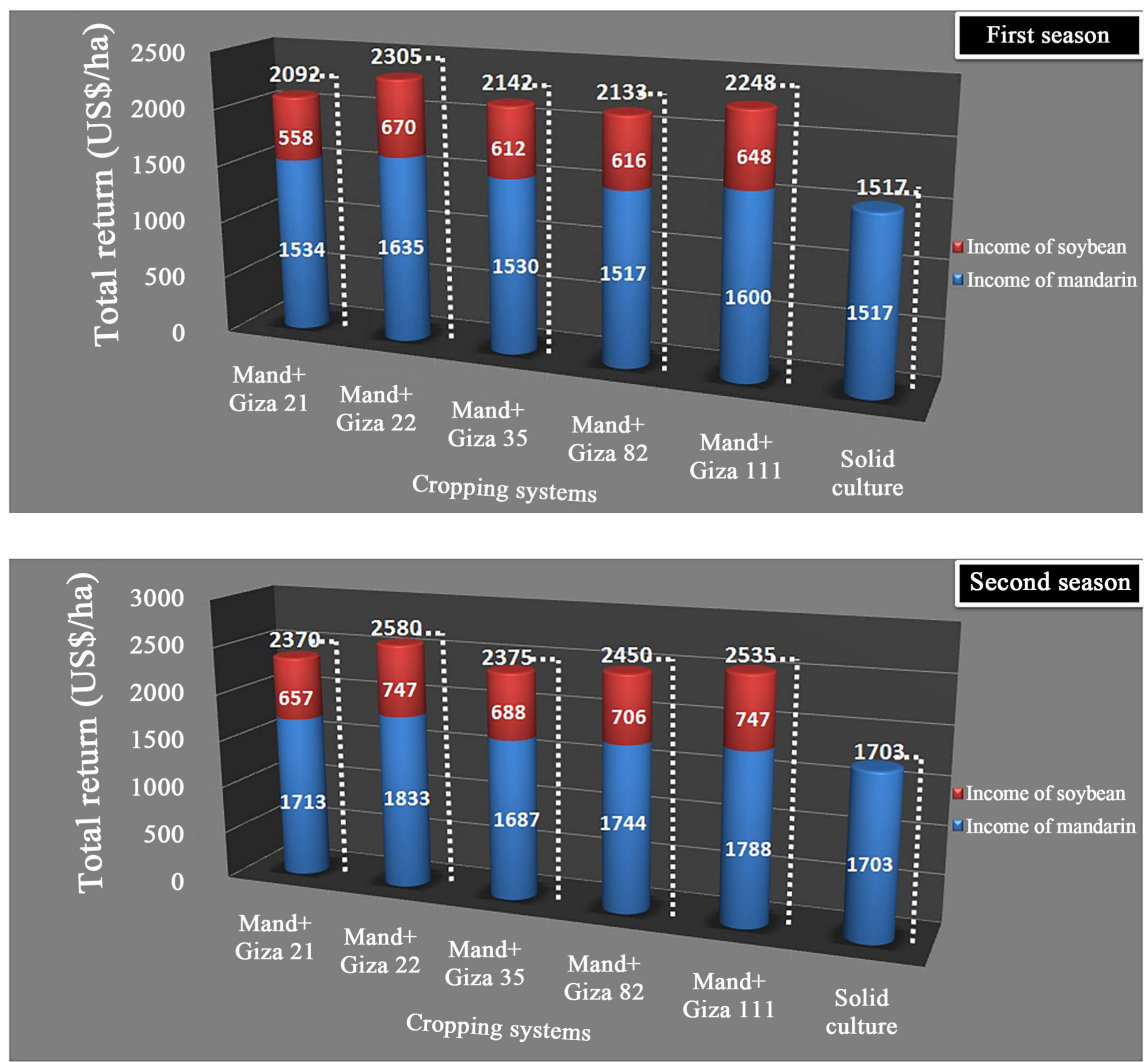

Figure 3. Incomes of mandarin and soybean and total return of interplanting some soybean cultivars with mandarin in both seasons. 


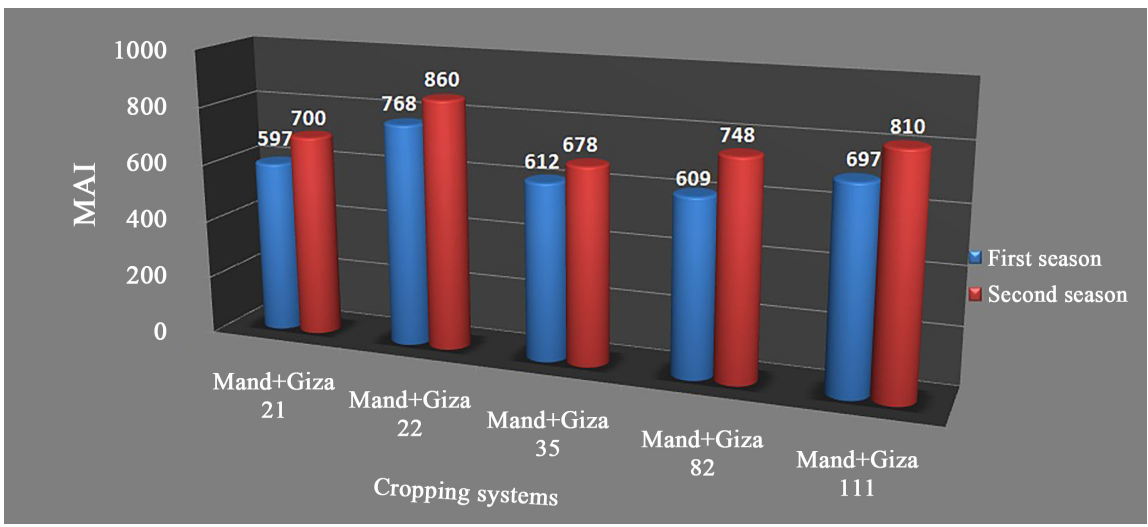

Figure 4. MAI of interplanting some soybean cultivars with mandarin in both seasons.

\section{Conclusion}

It can be concluded that improving production and fruit quality of mandarin depends on the choice of suitable soybean cultivars under interplanting conditions. Interplanting soybean cultivar Giza 22 with mandarin trees gave higher total count of rhizobia in rhizosphere of mandarin roots after 75 days from soybean sowing than the other treatments in both seasons. Soybean cultivars Giza 22 and Giza 111 are more compatible with adverse effects of mandarin trees than soybean cultivars Giza 21, Giza 35 and Giza 82 under interplanting. Soybean cultivars Giza 22 and Giza 111 had a higher competitive ability, productivity and economic advantage under interplanting with mandarin trees.

\section{Conflicts of Interest}

The authors declare no conflicts of interest regarding the publication of this paper.

\section{References}

[1] Salem, S.E. and Sheta, I. (2002) Citriculture and Genetic Resources in Egypt: State of the Art. In: D'Onghia, A.M., Djelouah, K. and Roistacher, C.N., Eds., Proceedings of the Mediterranean Research Network on Certification of Citrus (MNCC): 1998-2001, CIHEAM, Bari, 27-29.

[2] Abou-Zeed Eman, A.A., El-Salhy, A.M., Abdel-Galil, H.A. and Badawy Ebtsam, F.M. (2014) Effect of Yeast and Different Phosphorus Fertilizer Sources on Growth and Fruiting of Balady Mandarin Trees. Assiut Journal of Agricultural Sciences, 45, 49-64. https://doi.org/10.21608/ajas.2014.869

[3] Ragab, M.A. (2006) Response of Balady Mandarin Trees to Drip Irrigation and Nitrogen Fertilization. PhD Thesis Fac. of Agric. Minya University, Minya.

[4] Helail, B.M., El-Badawy, H.E., Zaied, N.S. and Seyam, G.A. (2012) A Comparative Study on the Effect of Traditional and Controlled Release N Fertilizers on Fruiting and Fruit Quality of Balady Mandarin Trees. Research Journal of Agriculture and Biological Sciences, 8, 115-126.

[5] FAO (2017) Citrus Fruit-Fresh and Processed. Annual Statistics. Rome.

[6] Lachungpa, K. (2004) Intercropping of Agri/Horti Crops with Special Reference to 
Mandarin (Citrus reticulata Blanco) in Sikkim, India. 4th International Crop Science Congress, Brisbane, 26 September - 1 October 2004, 1954.

[7] Srivastava, A.K., Huchche, A.D., Ram, L. and Singh, S. (2007) Yield Prediction in Intercropped versus Mono-Cropped Citrus Orchards. Scientia Horticulturae, 114, 67-70. https://doi.org/10.1016/j.scienta.2007.05.005

[8] Aziz, R.A.A., Salem, S.E. and Al-Bitar, L. (2008) Effect of Intercropping Cover Crops on Citrus Orchards Growth and Fruiting under Toshka Conditions. Journal of Agriculture and Veterinary Sciences, 1, 101-110.

[9] Hungria, M. and Mendes, I.C. (2015) Nitrogen Fixation with Soybean: The Perfect Symbiosis? In: de Bruijn, F., Ed., Biological Nitrogen Fixation, John Wiley \& Sons, Inc., Hoboken, Chapter 99, Vol. 2, 1005-1019. https://doi.org/10.1002/9781119053095.ch99

[10] Andrews, M. and Andrews, M.E. (2017) Specificity in Legume-Rhizobia Symbioses. International Journal of Molecular Sciences, 18, E705. https://doi.org/10.3390/ijms18040705

[11] Dixon, R.O.D. and Wheeler, C.T. (1986) Nitrogen Fixation in Plants. Blackie, Glasgow.

[12] Sprent, J.I. and Sprent, P. (1990) Nitrogen Fixing Organisms. Pure and Applied Aspects. Chapman \& Hall, London. https://doi.org/10.1007/978-94-009-0415-6

[13] Hardarson, G. (1993) Methods for Enhancing Symbiotic Nitrogen Fixation. Plant Soil, 152, 1-17. https://doi.org/10.1007/BF00016329

[14] Boote, K.J., Mínguez, M.I. and Sau, F. (2002) Adapting the CROPGRO Legume Model to Simulate Growth of Faba Bean. Agronomy Journal, 94, 743-756. https://doi.org/10.2134/agronj2002.0743

[15] Robertson, M.J., Carberry, P.S., Huth, N.I., Turpin, J.E., Probert, M.E., Poulton, P.L., Bell, M., Wright, G.C., Yeates, S.J. and Brinsmead, R.B. (2002) Simulation of Growth and Development of Diverse Legume Species in APSIM. Australian Journal of Agricultural Research, 53, 429-446. https://doi.org/10.1071/AR01106

[16] Graham, P.H. and Vance, C.P. (2003) Legumes: Importance and Constraints to Greater Use. Plant Physiology, 131, 872-877. https://doi.org/10.1104/pp.017004

[17] Maier, R.J. and Brill, W.J. (1978) Mutant Strains of Rhizobium japonicum with Increased Ability to Fix Nitrogen for Soybean. Science, 201, 448-450. https://doi.org/10.1126/science.201.4354.448

[18] Peterson, T.G. and LaRue, T.A. (1983) Nitrogen Fixation by Soybeans: Seasonal and Cultivar Effect, and Comparison of Estimates. Crop Science, 23, 488-492. https://doi.org/10.2135/cropsci1983.0011183X002300030012x

[19] Pedersen, P. (2003) Soybean Seed Inoculation. Integrated Crop Management. Iowa State University, Ames. http://www.ipm.iastate.edu

[20] Chapman, H.D. and Pratt, P.E. (1961) Methods of Analysis for Soil, Plant and Water. Division Agric. Sci., California University, Oakland.

[21] Alexander, M. and Clark, F. (1965) Chemical and Microbiological Properties. In: Black, et al., Eds., Methods of Soil Analysis, Agronomy Series, No. 9, American Society of Agronomy, Madison, 1550-1572

[22] Holden, M. (1965) Chlorophyll. In: Goodwin, T.W., Ed., Chemistry and Biochemistry of Plant Pigments, Academic Press, London, 462-488.

[23] Mead, R. and Willey, R.W. (1980) The Concept of a "Land Equivalent Ratio" and Advantages in Yields from Intercropping. Experimental Agriculture, 16, 217-228. 
https://doi.org/10.1017/S0014479700010978

[24] Adetiloye, P.O., Ezedinma, F.O.C. and Okigbo, B.N. (1983) A Land Equivalent Coefficient Concept for the Evaluation of Competitive and Productive Interactions on Simple Complex Mixtures. Ecological Modelling, 19, 27-39. https://doi.org/10.1016/0304-3800(83)90068-6

[25] Willey, R.W. (1979) Intercropping Its Importance and Research Needs. Part I: Competition and Yield Advantages. Field Crops Abstract, 32, 1-10.

[26] Freed, R.D. (1991) MSTATC Microcomputer Statistical Program. Michigan State University, East Lansing.

[27] Gomez, K.A. and Gomez, A.A. (1984) Statistical Procedures for Agricultural Research. 2nd Edition, John Willey and Sons, Toronto.

[28] Metwally, A.A., Shafik, M.M., El-Habbak, K.E. and Abdel-Wahab, Sh.I. (2012) Yield and Soybean Characters under Some Intercropping Patterns with Corn. Soybean Research, 10, 24-42.

[29] Abdel-Galil, A.M., Abdel-Wahab, Sh.I. and Abdel-Wahab, T.I. (2014) Compatibility of Some Maize and Soybean Varieties for Intercropping under Sandy Soil Conditions. Proceedings of 1 st Conference of International Soybean Research, Indore, 22-24 February 2014, 160.

[30] Lindemann, W.C. and Glover, C.R. (2013) Nitrogen Fixation by Legumes. The College of Agricultural, Consumer and Environmental Sciences. http://aces.nmsu.edu

[31] Lovatt, C.J., Zheng, Y. and Hake, C.D. (1988) Demonstration of a Change in Nitrogen Metabolism Influencing Flower Initiation in Citrus. Israel Journal of Botany, 37, 181-188.

[32] Nassib, A.M., Rammah, A. and Hussein, A.H.A. (1988) The Role of Legume in The Farming System of Egypt. In: Osman, A.E., Ibrahim, M.H. and Jones, M.A., Eds., The Role of Legumes in the Farming Systems of the Mediterranean Areas, Springer, Dordrecht, 51-61. https://doi.org/10.1007/978-94-009-1019-5_4

[33] Arshad, M., Hussain, N., Schmeiskyc, H. and Rasheed, M. (2016) Enhancing Soil Fertility through Intercropping, Inoculation and Fertilizer. Pakistan Journal of Scientific and Industrial Research, 59, 1-5.

[34] Franciosi, R., Salas, P., Mercabe, D. and Duarte, O. (1985) Supplementary Foliar Application of N, P and K to Washington Novel Orange Trees Affected by Tristiza. Proceedings of the Tropical Region, American Society for Horticultural Science, 24, 73-76.

[35] Postgate, J. (1998) Nitrogen Fixation. 3rd Edition, Cambridge University Press, Cambridge. http://www.cambridgeforecast.org

[36] Cattelan, A.J., Hartel, P.G. and Fuhrmann, J.J. (1999) Screening for Plant GrowthPromoting Rhizobacteria to Promote Early Soybean Growth. Soil Science Society of America Journal, 63, 1670-1680. https://doi.org/10.2136/sssaj1999.6361670x

[37] Sivakumar, M.V.K. and Virmani, S.M. (1980) Growth and Resource Use of Maize, Pigeonpea and Maize/Pigeonpea Intercrop in an Operational Research Watershed. Experimental Agriculture, 16, 377-386. https://doi.org/10.1017/S0014479700012035

[38] Odeleye, F.O., Togun, A.O. and Tayo, T.O. (2001) The Effect of Light Intensity on the Growth, Development and Yield of Soybean in Southwest Nigeria. African Crop Science Journal, 9, 577-590. https://doi.org/10.4314/acsj.v9i3.27603

[39] Noureldin, N.A., Hassan, M.Z., Hassaan, R.K. and Abdel-Wahab, Sh.I. (2002) Per- 
formance of Some Soybean Genotypes in Sandy Soil as Influenced by Some Abiotic Stresses. II. Effect on Seed Yield and Some Yield Attributes. Annals of Agricultural Sciences, 47, 209-223.

[40] Board, J.E. and Harville, B.G. (1992) Explanations for Greater Light Interception in Narrow- vs. Wide-Row Soybean. Crop Science, 32, 198-202. https://doi.org/10.2135/cropsci1992.0011183X003200010041x

[41] Liu, B., Liu, X.B., Wang, C., Li, Y.S., Jin, J. and Herbert, S.J. (2010) Soybean Yield and Yield Component Distribution across the Main Axis in Response to Light Enrichment and Shading under Different Densities. Plant, Soil and Environment, 56, 384-392. https://doi.org/10.17221/189/2009-PSE

[42] Abdel-Wahab, T.I. and Abdel-Rahman Rehab, A. (2016) Response of Some Soybean Cultivars to Low Light Intensity under Different Intercropping Patterns with Maize. International Journal of Applied Agricultural Sciences, 2, 21-31. https://doi.org/10.11648/j.ijaas.20160202.11

[43] Eweida, M.H.T., Hagras, A.M., Osman, M.S. and Hussein, A.H.A. (1982) Productivity of Soybean and Maize As Affected by Intercropping Systems. Thesis, Al-Azhar University, Cario.

[44] Egbe, O.M. (2010) Effects of Plant Density of Intercropped Soybean with Tall Sorghum on Competitive Ability of Soybean and Economic Yield at Otobi, Benue State, Nigeria. Journals of Cereals and Oilseeds, 1, 1-10.

[45] Metwally, A.A., Safina, S.A., Abdel-Wahab, T.I., Abdel-Wahab, Sh.I. and Hefny, Y.A.A. (2018) Productivity of Soybean Varieties under Intercropping Culture with Corn in Egypt. Soybean Research, 16, 63-77.

[46] Gadallah, R.A. and Selim, T.A. (2016) Distributions of Soybean and Corn Plants in Intercropping and Solid Patterns. Soybean Research, 14, 14-31.

[47] Vandermeer, J. (1989) The Ecology of Intercropping. Cambridge University Press, Cambridge, 254 p. https://doi.org/10.1017/CBO9780511623523 